\title{
Impact of Digitalization on the Speed of Internationalization
}

\author{
Yan-Yin Lee ${ }^{1}$, Mohammad Falahat ${ }^{1}$, Bik-Kai Sia ${ }^{1}$ \\ ${ }^{1}$ Faculty of Accountancy and Management (FAM), Universiti Tunku Abdul Rahman (UTAR), Malaysia \\ Correspondence: Yan-Yin Lee, Faculty of Accountancy and Management, Universiti Tunku Abdul Rahman \\ (UTAR), Jalan Sungai Long 9, Bandar Sungai Long, 43000 Kajang, Selangor, Malaysia.
}

Received: February 14, 2019

Accepted: March 5, 2019

Online Published: March 13, 2019

doi:10.5539/ibr.v12n4p1

URL: https://doi.org/10.5539/ibr.v12n4p1

\begin{abstract}
Digitalization combined with globalization is the current megatrend that impacting the international business landscape and creates opportunities for new business models. Embracing digitalization enables firms for speedy internationalization. Although the phenomenon of early internationalization has received increasing attention in the field of International Entrepreneurship over the past decades, however, there is a lack of focus on the role of digitalization that allows a higher speed of internationalization. This paper proposes a model that highlights the moderating role of digitalization on international business competencies and speed of internationalization. We argue that small and medium enterprises able to enter international markets more rapidly due to the impact of digitalization. This study addresses a gap in the literature and practical development needs for better understanding the impact of digitalization on the speed of internationalization. The limitations and implications of this study will be discussed for theoretical development and future research direction.
\end{abstract}

Keywords: speed of internationalization, digitalization, international business competencies, small and medium enterprise, born global

\section{Introduction}

Globalization and digitalization facilitate born globals' internationalization. Born globals (Rennie, 1993) refer to small and medium enterprises (SMEs) that internationalize within 3 years from their official establishment. They usually enter the international market through exporting with more than $25 \%$ sales from international markets (Cavusgil \& Knight, 2015). Differ from traditional SMEs that mostly operate in their local market, born globals are not restricted by scarce resources and actively explore opportunities abroad.

Contextual variables such as institutional environment, economic situation, social-cultural and market condition affect the speed and degree of born global internationalization (Knight \& Liesch, 2016). Although researchers apply different criteria to define born global, it is commonly accepted as a term that describes firms that undergone speedy internationalization. Born global studies reveal the success factors for early and rapid internationalization can be categorized into three main factors, namely the entrepreneur (Cao \& Ma, 2009; Falahat, Knight, \& Alon, 2018; Kaur \& Sandhu, 2014), the organization (Knight \& Liesch, 2016; Øyna \& Alon, 2018) and its environment (Hagen \& Zucchella, 2014; Karjaluoto \& Huhtamäki, 2010).

Born global literature commonly agrees digital technology advancement has facilitated the international business of born globals (Sinkovics, Sinkovics, \& "Bryan" Jean, 2013; Zhang, Sarker, \& Sarker, 2013; Zhang \& Tansuhaj, 2007). Digital technologies lower the barriers to the acquisition of market information and cross-border communication. Capability to leverage digitalization is likely to accelerate the internationalization process of a firm.

Digitalization refers to on-going adoption and application of digital technologies by a firm (Noroozi et al., 2010). As digitalization is a megatrend that happening within the business context, its impact on born global internationalization worth investigation. Despite prior studies recognize the positive association between international business competencies and born global international performance, the discussion rarely includes digitalization (Knight \& Liesch, 2016). This study is in response to the calls for more research on the impact of digitalization on internationalization by Coviello, Kano, and Liesch (2017), Manyika et al. (2016), and Vahlne and Johanson (2017).

We integrate the understanding from born global and digitalization literature in this study. We posit the interplay between international business competencies and born global international performance is not independent from 
the influence of digitalization. Understanding the role of digitalization and its impact on born global international performance is salient to all policymakers and SME practitioners that would like to embrace digitalization for better international performance.

In this paper, we conceptualize the impact of digitalization on international business competencies and speed of internationalization. We address the research question about how digitalization impacting born global speed of internationalization. From the conceptual model, researchers could assess the contingent digitalization factor that influences the empirical results in international business research. Also, SME practitioners and policymakers could understand the urgency of digital transformation within their operating context.

\section{Literature Review}

\subsection{Model Development}

Born global literature (Knight \& Cavusgil, 1996; Oviatt \& McDougall,1994, 1999, 2005) mostly employs Resource-Based Theory (Barney, 1991; Barney, Ketchen, \& Wright, 2011) and Industrial Organization Theory (Porter, 1981) for clarification of born global accelerated internationalization. Grounded on these two theories, we develop a conceptual model that consists of international business competencies and digitalization. We posit these two variables must be investigated simultaneously for a better understanding of its joint effect on the speed of internationalization.

Global digitalization has gradually affected the domestic market of a firm. Buyers can reach various sellers around the world and worldwide exporters are growing. As a result, the domestic market may shrink due to the lack of purchase from domestic market in the current borderless marketplace. Thus, digitalization increases the export propensity of domestic SME as a firm survival strategy when they perceive any risk or as a firm growth strategy when they perceive an opportunity. Nevertheless, not every firm possess the capabilities to internationalize early. We argue that international business competencies are prerequisites for a firm to succeed in the context of digitalization.

Digitalization of business environment allows these firms to promote and sell their products at affordable cost. This mechanism is not working if they are operating in an export market without infrastructure readiness and non-digital oriented (Gregory, Karavdic, \& Zou, 2007). Similar to the impact of technology turbulence (Kaleka, 2012) on exporting firms, we argue that not all industries and markets are digitalized at the same pace, thus, not all firms able to adopt digitalization in their business model. The degree of digitalization affects the possibilities of a firm to internationalize early despite they are competent in international business. The conceptual model is outlined in Figure 1 and further will be discussed in the next section.

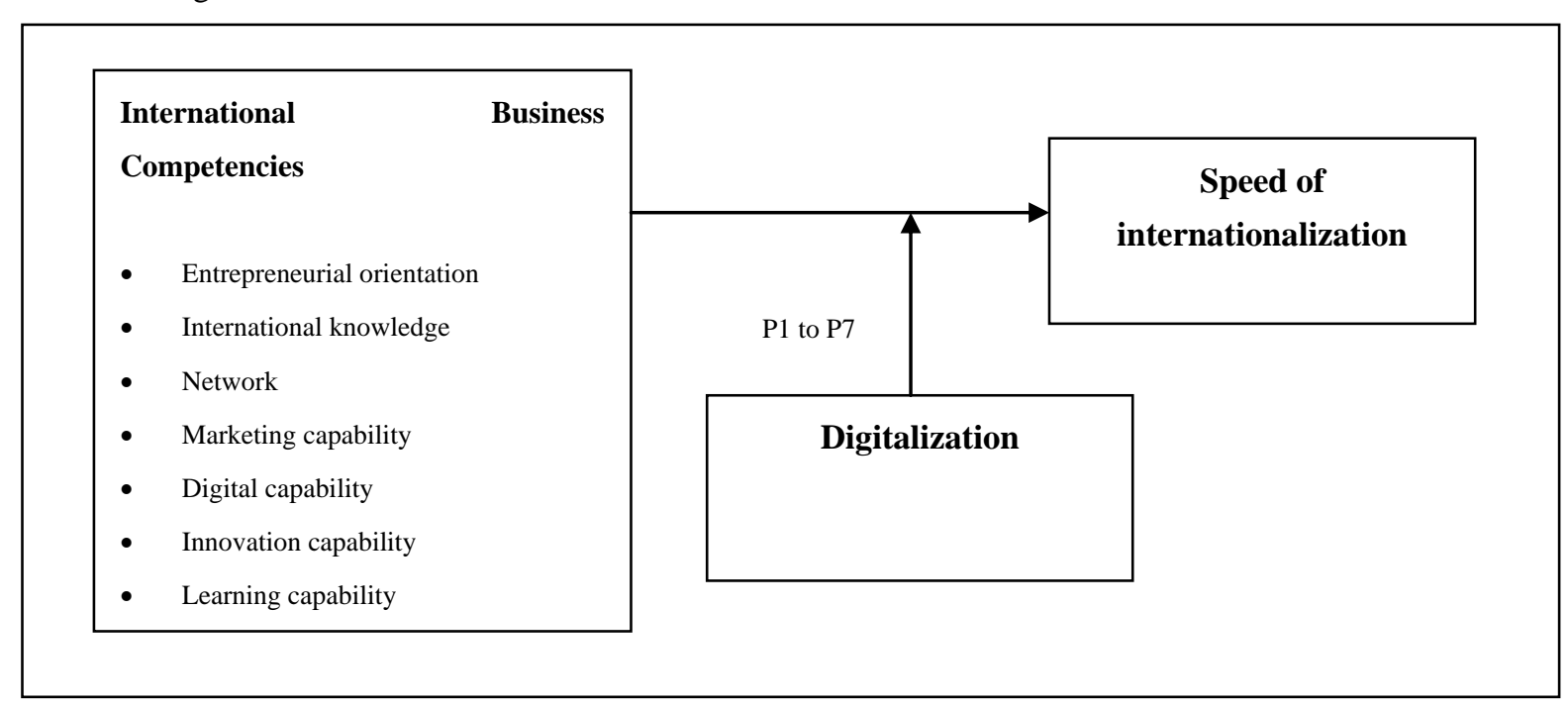

Figure 1. Conceptual model

\subsection{Propositions Development}

\subsubsection{Digitalization and Speed of Internationalization}

Digitalization facilitates knowledge acquisition and enhances business networking. It creates a business environment in which young exporters can learn fast and makes early and rapid internationalization possible (Johanson \& Vahlne, 2009). 
The effect of digitalization is critical for new venture internationalization in view that technological change is the foundation for speedy internationalization. It is the technological change in the last two decades that stimulated and facilitated the speedy internationalization of born globals (Oviatt \& McDougall, 1994, 1999). According to Knight and Cavusgil (2004), the born global phenomenon is triggered by globalization that has made internationalization easier than before and the advances in communication and transportation technologies have reduced the transaction cost.

Under the foundation of technological changes, the international business environment is favourable for a smaller firm to assess resources and to leverage their firm's capabilities for early and rapid internationalization (Pagani \& Pardo, 2017). Digitalization is therefore viewed as an opportunity for a small firm to enter the international market.

Owing to the adoption cost of digital technologies, digital transformation requires substantial investment (Choshin \& Ghaffari, 2017). SMEs have limited resources for trial and error; understanding the impact of digitalization is necessary for their results-based decision making. Firms under the pressure of competition due to market transparency and liberalization tend to expand their market for growth and survival (Krammer et al., 2017; Wilden, Gudergan, \& Nielsen, 2013).

Similar to the effects of globalization on firm performance (Knight, 2000), the impact of digitalization should be considered in international entrepreneurship. Many recent studies have been done for investigation of digitalization generally, but not specifically in born global context. Foroudi, Gupta, Nazarian and Duda (2017) found a positive influence of digital technology on a firm's marketing capability. Bouwman, Nikou, Molina-Castillo and Reuver (2018) observed digitalization impacting business models through innovation activity, strategy and technology turbulence. In the following section, we discuss the role of digitalization on international business competencies-performance relation.

Barney (1991) suggests that competitive advantage can only be generated and sustained by firm-level resources that are valuable, rare, inimitable and non-substitutable, only resources that are intangible in nature possess these criteria. Intangible resources are then becoming the focal point for the resource-based view (RBV) scholars. SMEs are characterized with limited tangible resources, intangible resources such as their international business competency is an important determinant for their success (Knight \& Kim, 2008). International business competencies refer to a set of international knowledge and skills to handle international business. Born global literature has explored the necessary resources and capabilities that lead to speedy internationalization (Falahat, Mohamad, \& Migin, 2013; Weerawardena, Mort, Liesch, \& Knight, 2007), but the impact of digitalization on this skill set has not been extensively discussed.

For speedy internationalization, born globals with limited slack resources must be able to allocate their focus to develop the resources and capabilities that are perceived to affect competitive advantages for firm performance. The deployment of different resources and capabilities will lead to different outcomes. A firm with growth strategies will have different deployment plan if compare with a firm with survival strategies. The higher investment will be allocated for growth, but the limited investment will be allocated for profit-oriented survival strategies (Prange \& Verdier, 2011). Born globals need to develop the right set of resources and capabilities that able to increase their chance to succeed in international market rapidly. In the below section, we discuss critical variables that give born global business competencies for speed of internationalization.

\subsubsection{Entrepreneurial Orientation}

According to new venture internationalization studies, born globals' entrepreneurial orientation is essential for their success (Knight \& Cavusgil, 2004). The proactiveness, innovativeness and risk-taking characteristics determine whether these firms willing to challenge the international market. In SME internationalization studies, entrepreneurial orientation is associated with firm performance (Cannone \& Ughetto, 2014; Falahat et al., 2018; Fernández-Mesa \& Alegre, 2015; Gerschewski, Rose, \& Lindsay, 2015; Gruber-Muecke \& Hofer, 2015; Zhang et al., 2013). Highly entrepreneurial firms are more committed to build the required capabilities that in line with their competitive strategies to excel (Weerawardena, 2003; Weerawardena et al., 2007). Entrepreneurial orientation is a necessitate factor that triggers early internationalization (Cavusgil \& Knight, 2015; Øyna \& Alon, 2018).

Among entrepreneurial firms, empirical findings showed that early internationalizing firms are mostly found in high-technology industries. These industries have an ecosystem that is more digitalized than traditional industries in their supply-chain activities from sourcing, purchasing, manufacturing and marketing. The digitalization of supply-chain among traditional industries also create opportunities for these firms to internationalize early (Gabrielsson and Gabrielsson, 2011). However, entrepreneurial firms that operating in a 
less digitalized environment would need to follow a step by step approach in their route of internationalization. Based on this, we propose:

P1: For SMEs with a strong emphasis on digitalization, the greater the entrepreneurial orientation, the greater the speed of internationalization

\subsubsection{International Knowledge}

International knowledge determines the commitment decisions for internationalization (Johanson \& Vahlne, 1977). From the experiential knowledge that gained during the international business activities, the firm has a better understanding of the opportunities or risks of the international business, thus able to increase their commitment stage by stage. This concept can be applied to born global firms as well (Johanson \& Vahlne, 2009). Although the born global firms normally export within 3 years from the inception, most of the founders of born global firms have prior international knowledge and experience which accelerate their decision making of internationalization commitment (Knight \& Liesch, 2016; Madsen \& Servais, 1997). Along the internationalization process, knowledge is the most critical asset of the firm to achieve competitive advantage (Ismail, Khurram, Abadi, \& Jafri, 2017; McDougall \& Oviatt, 2003). When firms obtain more market knowledge, they have a lower perception on environmental uncertainty in the foreign market, thus accelerate their exporting activities (Noroozi, Mobarekeh, \& Zadeh, 2010) and enhance their export performance (Oura, Zilber, \& Lopes, 2016).

Nevertheless, SMEs unable to accelerate the internationalization process by knowing the international business procedures or knowing the market needs. From a practical aspect, these knowledgeable firms must operate in an industry or a market that strongly affected by digitalization so that they could embrace the benefits of lower promotion and distribution cost. A knowledgeable firm that operating in a less digitalized context has to build substantial resources and business networks slowly, thus need a longer preparation time frame for internationalization. Hence, we propose:

P2: For SMEs that have a strong emphasis on digitalization, the greater the international knowledge, the greater the speed of internationalization

\subsubsection{Network}

Born global uses networks to overcome the constraints of scarce resources (Falahat, Migin, Chuan, \& Kong, 2015; Freeman \& Cavusgil, 2007; McDougall \& Oviatt, 2003). The strong relationships with local authorities, investors, business partners, suppliers, distributors, customers, multinational enterprises can help born global to create sustainable competitive advantages (Falahat et al., 2018).

Freeman, Edwards, and Schroder (2006) proposed that born global firms with poor access to economies of scale and lack of financial and knowledge resources can overcome the constraints through network and alliances. They suggested five workable strategies in order to achieve this outcome e.g. use of a personal network, collaborative partnerships, client followership, use of advanced technology and multiple modes of entry. Felzensztein, Ciravegna, Robson, and Amorós (2015) observed that the network plays a role in determining the internationalization scope. Zhou, $\mathrm{Wu}$, and $\mathrm{Luo}$ (2007) also found that social networks affect the internationalization orientation and firm performance. Hagen \& Zucchella (2014) stated that strategic partnership is one of the main differentiators in born global's growth patterns regardless of the industry type. According to Freeman, Hutchings, Lazaris, and Zyngier (2010), network also a source of new knowledge for smaller born global firms. Network allows born global to source for complementary resources and capabilities which the firm is lacking through outsourcing of the tasks to reliable alliances (Madsen \& Servais, 1997). Born globals can reach new business space faster by using the large channels provided by MNC partners (Gabrielsson \& Manek Kirpalani, 2004). Strong relationships with government as part of the network also enable SMEs to gain benefits from government support programmes (Faroque \& Takahashi, 2015). Krammer, Strange, and Lashitew (2017) found that access to external technology via licensing is one kind of relational resource that positively related to the export intensity of these firms. Many studies have found a positive relationship between network and firm performance (Kim \& Hemmert, 2016; Krammer et al., 2017; Zhou et al., 2007).

Information communication technology facilitates information exchange between SMEs and their business partners. Instead of face-to-face meeting, they can exchange market and product information through digital communication tools. Digital communication tools have shorten distance among people and help to maintain close relationships with business partners through social media sharing and discussion. Of course, this could happen only in the network where business partners are active in digital communication. Based on this, we propose:

P3: For SMEs that have a strong emphasis on digitalization, the greater the network, the greater the speed of internationalization 


\subsubsection{Marketing Capability}

Marketing capability is the strategic capability $($ Lenz, 1980) for a market-oriented firm. The ability of the firm to perform traditional marketing activities like proper segmentation-targeting-positioning of the market, and develop highly effective marketing $4 \mathrm{P}$ (product, price, place, promotion) strategies has brought them to international market (Weerawardena et al., 2007). Marketing capability helps a firm to gain sustained competitive advantage (Kamboj, Goyal, \& Rahman, 2015; Weerawardena, 2003). Several empirical evidences have shown the positive association of marketing capability with international performance (Ahmadi, Cass, \& Miles, 2014; Falahat \& Migin, 2017; Kamboj et al., 2015; Pham, Monkhouse, \& Barnes, 2017; Takahashi, Bulgacov, Semprebon, \& Giacomini, 2016). Firms with high marketing capability can develop marketing strategy that meets the customer requirements. This capability is salient especially when a firm intends to enter new market rapidly.

Digital technology has significantly lowered the cost of traditional marketing through the online platform. Many firms leverage digital tools such as Alibaba e-commerce, Facebook, Instagram, Youtube, Google search engine etc. to promote their products and services to the world. Nevertheless, fundamental marketing capability such as determining the right target customer, proper positioning of the product, effective pricing and market sensing are required to support effective implementation of digital marketing. Investing in digitalization not only influence on the speed of internationalization but it is, in fact, a profitable investment for the firms that meeting the conditions to succeed with e-Commerce (Bergendahl, 2005).

SMEs that operating in an environment that is ready for digital marketing can utilize it for early internationalization. We then propose:

P4: For SMEs that have a strong emphasis on digitalization, the greater the marketing capability, the greater the speed of internationalization

\subsubsection{Digital Capability}

Digital capability is a firm's ability to apply digital technologies for value creation in their business activities. It is distinguished from the definition for Information Technology (IT) capability which is "the relative capabilities that help an organization create technical and market knowledge and facilitates intra-organizational communication flow" (Song, Nason, \& Di Benedetto, 2008). Digital capability covers more than information flow and communication flow.

Technological change is the foundation of new venture internationalization (McDougall \& Oviatt, 2003; Oviatt \& McDougall, 1994, 1999). Born global's capability to adopt digital technologies such as the internet, digital marketing tools, e-commerce, big data, internet of things, cloud computing etc. in their business can directly or indirectly create competitive advantages in the digital economy. Several empirical findings had shown that adoption of one or more digital technologies leads to better international performance (Eggers, Hatak, Kraus, \& Niemand, 2017; Gabrielsson \& Gabrielsson, 2011; Gregory, Ngo, \& Karavdic, 2017; Zhang \& Tansuhaj, 2007). Firm possesses digital capability can utilize digital technology to optimize their processes, to support the creation of new products or services or to further support the bonding with business partners in their network (Pagani \& Pardo, 2017). Hence, digital capability is likely to assist new venture in entering international market early.

Despite there is a psychic distance from countries to countries, digital products and services are more universal as compared with traditional products such as food, clothing and furniture. Firms with the digital capability that operating within an environment that favourable for selling of digital products or services would internationalize earlier than firms with products that restricted by demand and interest differences from one market to another.

Digital technologies such as automation, cyber-physical system etc. help firms to optimize their productivity. SMEs can adopt automation to increase their capacity. Nevertheless, the justification of investment for automation and availability of technology depends on the operating ecosystem, their customer preference and competitors' action.

In addition, firms with strong digital marketing capability can utilize this tool to boost company branding and market their products at a lower cost. However, this strategy is workable only if their target market is ready with a mature online infrastructure. So, we propose:

P5: For SMEs that have a strong emphasis on digitalization, the greater the digital capability, the greater the speed of internationalization

\subsubsection{Innovation Capability}

The concept of innovation is broad and there are many definitions of innovation from different scholars 
(Kotsemir \& Abroskin, 2013). We adopt the definition from OECD Oslo Manual, 3rd edition (OECD, 2005) which categorize innovation into four types, namely product innovation, process innovation, marketing innovation and organizational innovation.

Innovation is linked with born global phenomenon by Knight and Cavusgil (2004) in the award-winning article "Innovation, organizational capabilities, and the born-global firm". According to the 2004 article, the innovation capability in offering new product and developing new market is essential for the success of born global firm (Knight \& Cavusgil, 2004). Innovative capability is one of the important factors which allows born global firm to accelerate internationalization process despite scarce resources. Both technological and non-technological innovation can lead to sustained competitive advantage (Weerawardena, 2003). For example, innovation capability enhances a firm's ability to develop innovative products and increase its speed in introducing the products to the market (Sok \& Cass, 2011). Several empirical findings acknowledge the contribution of innovation to firm performance (Oura et al., 2016; Raymond, Bergeron, \& Croteau, 2013; Sok \& Cass, 2011; Wu, Chen, \& Jiao, 2016). When confronting with competitors around the world, innovation capability determines the product and service uniqueness which accelerate market entry (Knight \& Cavusgil, 2004).

Apart from innovativeness, SMEs rely on effective distribution channel which they could promote their offerings within an affordable budget. Depending on the target market readiness, not all products can be easily sold online (Gregory, Karavdic, \& Zou, 2007). Those innovative firms who can sell their unique products through an online platform can reach the market faster than others who rely on traditional distribution methods. Hence, we propose:

P6: For SMEs that have a strong emphasis on digitalization, the greater the innovation capability, the greater the speed of internationalization

\subsubsection{Learning Capability}

The role of learning capability is essential to ensure the continuity of existing competitiveness in international market (Johanson \& Vahlne, 2009). A firm without learning capability is difficult to sustain in long run because of failure to develop the capabilities required for a sustainable competitive advantage in facing future challenges (Grant, 1991; Teece, Pisano, \& Shuen, 1997). It is necessary to develop and maintain market-focused learning capability and internally-focused learning capability for accelerated internationalization, these capabilities will enable the firm to develop knowledge-intensive products (Weerawardena et al., 2007). Technological learning capability provides the advantages of quick response to market needs and therefore able to increase financial returns (Zahra, Ireland, \& Hitt, 2000). New venture with minimal knowledge and information about foreign market needs to leverage their learning capability to overcome all possible challenges during the internationalization process (McDougall \& Oviatt, 2003). Thus, learning capability is found to be positively associated with international performance (Evangelista \& Mac, 2016; Fernández-Mesa \& Alegre, 2015; Sok \& Cass, 2011).

Among firms with learning capability, availability of online knowledge resource determines the speed of knowledge acquisition. SMEs operating in an industry that strongly affected by digitalization are more likely to gain product and market information from the digital platform as compared with SMEs operating in a traditional industry which has limited digitized information. When product and market knowledge can generally obtain from the internet with minimal cost, SMEs that capable to learn can reap the benefits from the knowledge treasure. Thus, we propose:

P7: For SMEs that have a strong emphasis on digitalization, the greater the learning capability, the greater the speed of internationalization

Practically, firm's digitalization affects the strength of the relationship between their international business competencies and speed of internationalization. For instance, a software company that operates on a digital platform can sell their products internationally without much transportation cost, but a traditional business without online customers is forced to follow the traditional way of business networking through huge investment for trade fair and face-to-face meetings. Despite both may have similar marketing competency, the software company is likely to internationalize early.

\section{Method}

In developing the conceptual model, the methodology applied is qualitative. The main aim is to scrutinize the interaction between firm's international business competencies and the impact of digitalization. We develop a model based on literature review (Marek, 2015). We used Science Direct and Google Scholar for article 
searching. First, we applied keywords such as "born global", "early internationalization", "rapid internationalization", "speed of internationalization" and "international new venture" to search for papers related to success factors for the speed of internationalization. We conduct a literature review on factors affect born global speed of internationalization. To delineate the boundaries of the study, we focus on articles that discuss international business competencies for born global early internationalization and attempt to identify any born global research papers that discuss digitalization. In view of born global literature that concerning the impact of digitalization is scarce (Øyna \& Alon, 2018), further on, we conduct a literature review on digitalization literature for an understanding of the impact of digitalization on firms' performance. For this purpose, we applied keywords such as "digitalization", "digital capability", "digital orientation", "IT capability", "Industry 4.0", "digital technology" to search for digitalization related papers. Subsequently, based on a review from born global literature and digitalization literature, we propose the conceptual model.

\section{Implications and Conclusion}

This paper has its theoretical implication on born global internationalization literature. We extend the understanding of the role of digitalization on the relationship between international business competencies and speed of internationalization. We connect the internal intangible resources and capabilities with industry related factor (digitalization) for a holistic view on born global speedy internationalization. The conceptual model is complementing born global capability-performance studies that mostly ignore the impact of digitalization.

Despite the conceptual model has not been empirically tested, there are few managerial implications for SMEs and policymakers who wish to embrace digitalization for speedy internationalization. First, the development of international business competencies is a prerequisite for speedy internationalization in digitalization context. Second, digitalization should be considered as an important step to internationalize early and rapidly. Third, policymakers can customize export acceleration program through assessment of current digitalization status among different types of industries. Industries that strongly impacted by digitalization need more assistance to develop fundamental international business skills, digital skills and adopt digital technologies. These firms are more likely to internationalize early and rapidly if they could develop necessary international business competencies to exploit digitalization trends.

The integrated view of digitalization for speedy internationalization is the main concept of the study. This paper conceptualizes the impact of digitalization on international business competencies for the speed of internationalization. We propose the important role of digitalization in the international arena. We argue that firms which able to ride on digitalization wave can internationalize earlier than other firms. Yet, more empirical studies are needed to examine this argument. As digitalization is an irreversible trend, integration of digitalization in international business studies is desperately in need.

\section{Acknowledgements}

This paper was supported by the Malaysia Ministry of Education (MOE) under FRGS scheme (FRGS/1/2017/SS01/UTAR/02/3).

\section{References}

Ahmadi, H., Cass, A. O., \& Miles, M. P. (2014). Product resource - capability complementarity , integration mechanisms, and first product advantage. Journal of Business Research, 67(5), 704-709. https://doi.org/10.1016/j.jbusres.2013.11.031

Barney, J. B. (1991). Firm resources and sustained competitive advantage. Journal of Management, 17(1), 99-120. https://doi.org/10.1177/014920639101700108

Barney, J. B., Ketchen Jr, D. J., \& Wright, M. (2011). The future of resource-based theory: revitalization or decline?. Journal of Management, 37(5), 1299-1315. https://doi.org/10.1177/0149206310391805

Bergendahl, G. (2005). Models for investment in electronic commerce-financial perspectives with empirical evidence. Omega, 33(4), 363-376. https://doi.org/10.1016/j.omega.2004.07.021

Bouwman, H., Nikou, S., Molina-Castillo, F. J., \& de Reuver, M. (2018). The impact of digitalization on business models. Digital Policy, Regulation and Governance, 20(2), 105-124. https://doi.org/10.1108/DPRG-07-2017-0039

Cannone, G., \& Ughetto, E. (2014). Born globals: A cross-country survey on high-tech start-ups. International Business Review, 23(1), 272-283. https://doi.org/10.1016/j.ibusrev.2013.05.003

Cao, C. X., \& Ma, H. Y. (2009). Business, network, and entrepreneur: The drivers of rapid internationalization of the born global firms. In Proceedings - International Conference on Management and Service Science, 
MASS 2009. https://doi.org/10.1109/ICMSS.2009.5301707

Cavusgil, S. T., \& Knight, G. (2015). The born global firm: An entrepreneurial and capabilities perspective on early and rapid internationalization. Journal of International Business Studies, 46(1), 3-16.

https://doi.org/10.1057/jibs.2014.62

Choshin, M., \& Ghaffari, A. (2017). An investigation of the impact of effective factors on the success of e-commerce in small-and medium-sized companies. Computers in Human Behavior, 66, 67-74. https://doi.org/10.1016/j.chb.2016.09.026

Coviello, N., Kano, L., \& Liesch, P. W. (2017). Adapting the Uppsala Model to a modern world: Macro-Context and Microfoundations. Journal of International Business Studies, 48(9), 1151-1164. https://doi.org/10.1057/s41267-017-0120-x

Eggers, F., Hatak, I., Kraus, S., \& Niemand, T. (2017). Technologies that support marketing and market development in SMEs - evidence from social networks. Journal of Small Business Management, 55(2), 270-302. https://doi.org/10.1111/jsbm.12313

Evangelista, F., \& Mac, L. (2016). The influence of experience and deliberate learning on SME export performance. International Journal of Entrepreneurial Behavior \& Research, 22(6), 860-879. https://doi.org/10.1108/IJEBR-12-2015-0300

Falahat, M., Knight, G., \& Alon, I. (2018). Orientations and capabilities of born global firms from emerging markets. International Marketing Review, 35(6), 936-957. https://doi.org/10.1108/IMR-01-2017-0021

Falahat, M., \& Migin, M. W. (2017). Export performance of international new ventures in emerging market. International Journal of Business and Globalization, 19(1), 111-125. https://doi.org/10.1504/IJBG.2017.085119

Falahat, M., Migin, M. W., Chuan, C. S., \& Kong, P. F. (2015). Conceptualising the early and rapid internationalizing firms. Procedia - Social and Behavioral Sciences, 211(September), 612-618. https://doi.org/10.1016/j.sbspro.2015.11.080

Falahat, M., Mohamad, O., \& Migin, M. W. (2013). Born global firms in developing economies: the case of Malaysia. Australian Journal of Basic and Applied Sciences, 7(4), 586-594.

Faroque, A. R., \& Takahashi, Y. (2015). Export marketing assistance and early internationalizing firm performance: Does export commitment matter? Asia Pacific Journal of Marketing and Logistics, 27(3), 421-443. https://doi.org/http://dx.doi.org/10.1108/APJML-03-2014-0045

Felzensztein, C., Ciravegna, L., Robson, P., \& Amorós, J. E. (2015). Networks, entrepreneurial orientation, and internationalization scope: Evidence from Chilean small and medium enterprises. Journal of Small Business Management, 53, 145-160. https://doi.org/10.1111/jsbm.12188

Fernández-Mesa, A., \& Alegre, J. (2015). Entrepreneurial orientation and export intensity: Examining the interplay of organizational learning and innovation. International Business Review, 24(1), 148-156. https://doi.org/10.1016/j.ibusrev.2014.07.004

Foroudi, P., Gupta, S., Nazarian, A., \& Duda, M. (2017). Digital technology and marketing management capability: achieving growth in SMEs. Qualitative Market Research: An International Journal, 20(2), 230-246. https://doi.org/10.1108/QMR-01-2017-0014

Freeman, S., \& Cavusgil, S. T. (2007). Toward a typology of commitment states among managers of born-global firms: A study of accelerated internationalization. Journal of International Marketing, 15(4), 1-40. https://doi.org/10.1509/jimk.15.4.1

Freeman, S., Edwards, R., \& Schroder, B. (2006). How smaller born-global firms use networks and alliances to overcome constraints to rapid internationalization. Journal of International Marketing, 14(3), 33-63. https://doi.org/10.1509/jimk.14.3.33

Freeman, S., Hutchings, K., Lazaris, M., \& Zyngier, S. (2010). A model of rapid knowledge development: The smaller born-global firm. International Business Review, 19(1), 70-84. https://doi.org/10.1016/j.ibusrev.2009.09.004

Gabrielsson, M., \& Gabrielsson, P. (2011). Internet-based sales channel strategies of born global firms. International Business Review, 20(1), 88-99. https://doi.org/10.1016/j.ibusrev.2010.05.001

Gabrielsson, M., \& Manek Kirpalani, V. H. (2004). Born globals: How to reach new business space rapidly. 
International Business Review, 13(5), 555-571. https://doi.org/10.1016/j.ibusrev.2004.03.005

Gerschewski, S., Rose, E. L., \& Lindsay, V. J. (2015). Understanding the drivers of international performance for born global firms: An integrated perspective. Journal of World Business, 50(3), 558-575. https://doi.org/10.1016/j.jwb.2014.09.001

Grant, R. M. (1991). The resource-based theory of competitive advantage: implications for strategy formulation. California management review, 33(3), 114-135. https://doi.org/10.1016/B978-0-7506-7088-3.50004-8

Gregory, G. D., Ngo, L. V., \& Karavdic, M. (2017). Developing e-commerce marketing capabilities and efficiencies for enhanced performance in business-to-business export ventures. Industrial Marketing Management. Retrieved from http://dx.doi.org/10.1016/j.indmarman.2017.03.002

Gregory, G., Karavdic, M., \& Zou, S. (2007). The Effects of E-Commerce Drivers on Export Marketing Strategy. Journal of International Marketing, 15(2), 30-57. https://doi.org/10.1509/jimk.15.2.30

Gruber-Muecke, T., \& Hofer, K. M. (2015). Market orientation, entrepreneurial orientation and performance in emerging markets. International Journal of Emerging Markets, 10(3), 560-571. https://doi.org/10.1108/JHOM-09-2016-0165

Hagen, B., \& Zucchella, A. (2014). Born Global or Born to Run? The Long-Term Growth of Born Global Firms. Management International Review, 54(4), 497-525. https://doi.org/10.1007/s11575-014-0214-7

Ismail, K., Khurram, W., Abadi, M. D., \& Jafri, S. K. A. (2017). Sustained Competitive Advantage of Malaysian Born Global SMES: Role of International Entrepreneurial Capability and Positive Psychological Capital. Advanced Science Letters, 23(9), 8924-8928. https://doi.org/10.1166/asl.2017.9996

Johanson, J., \& Vahlne, J. E. (1977). The internationalization process of the firm-a model of knowledge development and increasing foreign market commitments. Journal of International Business Studies, 8(1), 23-32. https://doi.org/10.1057/palgrave.jibs.8490676

Johanson, J., \& Vahlne, J. E. (2009). The Uppsala internationalization process model revisited: From liability of foreignness to liability of outsidership. Journal of International Business Studies, 40(9), 1411-1431. https://doi.org/10.1057/jibs.2009.24

Kaleka, A. (2012). Studying resource and capability effects on export venture performance. Journal of World Business, 47(1), 93-105. https://doi.org/10.1016/j.jwb.2010.10.024

Kamboj, S., Goyal, P., \& Rahman, Z. (2015). A resource-based view on marketing capability, operations capability and financial performance: An empirical examination of mediating role. Procedia - Social and Behavioral Sciences, 189, 406-415. https://doi.org/10.1016/j.sbspro.2015.03.201

Karjaluoto, H., \& Huhtamäki, M. (2010). The role of electronic channels in micro-sized brick-and-mortar firms. Journal of Small Business \& Entrepreneurship, 23(1), 17-38. https://doi.org/10.1080/08276331.2010.10593471

Kaur, S., \& Sandhu, M. S. (2014). Internationalisation of born global firms: Evidence from Malaysia. Journal of the Asia Pacific Economy, 19(1), 101-136. https://doi.org/10.1080/13547860.2013.818426

Kim, J. J., \& Hemmert, M. (2016). What drives the export performance of small and medium-sized subcontracting firms? A study of Korean manufacturers. International Business Review, 25(2), 511-521. https://doi.org/10.1016/j.ibusrev.2015.09.002

Knight, G. (2000). Entrepreneurship and marketing strategy: The SME under globalization. Journal of International Marketing, 8(2), 12-32. https://doi.org/10.1509/jimk.8.2.12.19620

Knight, G. A., \& Cavusgil, S. T. (1996). The born global firm: A challenge to traditional internationalization theory. Advances in International Marketing, 8, 11-26.

Knight, G. A., \& Cavusgil, S. T. (2004). Innovation, organizational capabilities, and the born-global firm. Journal of International Business Studies, 35(2), 124-141. https://doi.org/10.1057/palgrave.jibs.8400071

Knight, G. A., \& Kim, D. (2008). International business competence and the contemporary firm. Journal of International Business Studies, 40(2), 255-273. https://doi.org/10.1057/palgrave.jibs.8400397

Knight, G. A., \& Liesch, P. W. (2016). Internationalization: From incremental to born global. Journal of World Business, 51(1), 93-102. https://doi.org/10.1016/j.jwb.2015.08.011

Kotsemir, M., \& Abroskin, A. (2013). Innovation concepts and typology: An evolutionary discussion innovation concepts and typology. MPRA Paper. Retrieved from 
https://mpra.ub.uni-muenchen.de/45400/1/MPRA_paper_45069.pdf

Krammer, S. M. S., Strange, R., \& Lashitew, A. (2017). The export performance of emerging economy firms: The influence of firm capabilities and institutional environments. International Business Review, 27(1), 218-230. https://doi.org/10.1016/j.ibusrev.2017.07.003

Lenz, R. T. (1980). Strategic Capability: A Concept and Framework for Analysis. Academy of Management, 5(2), 225-234.

Madsen, T. K., \& Servais, P. (1997). The internationalization of Born Globals: An evolutionary process? International Business Review, 6(6), 561-583. https://doi.org/10.1016/S0969-5931(97)00032-2

Manyika, J., Lund, S., Bughin, J., Woetzel, J., Stamenov, K., \& Dhingra, D. (2016). Digital Globalization: The new era of global flows. New York: McKinsey Global Institute. Retrieved from http://www.mckinsey.com/business-functions/digital-mckinsey/our-insights/digital-globalization-the-new-er a-of-global-flows

Marek, M. (2015). Conceptual Paper Outline. https://doi.org/10.13140/RG.2.1.4962.5768.

McDougall, P. P., \& Oviatt, B. M. (2003). Some fundamental issues in international entrepreneurship. Entrepreneurship Theory \& Practice, 18, 1-27. https://doi.org/10.1017/CBO9781107415324.004

Noroozi, A., Mobarekeh, A. N., \& Zadeh, H. F. (2010). The impact of e-commerce on export development in developing countries: A case of small and medium-sized enterprises in Iran and Malaysia. In 2010 2nd IEEE International Conference on Information Management and Engineering, 435-439. https://doi.org/10.1109/ICIME.2010.5477703

OECD. (2005). Oslo manual. Guidelines for collecting and interpreting innovation data (3rd ed.). Paris: OECD EUROSTAT.

Oura, M. M., Zilber, S. N., \& Lopes, E. L. (2016). Innovation capacity, international experience and export performance of SMEs in Brazil. International Business Review, 25(4), 921-932. https://doi.org/10.1016/j.ibusrev.2015.12.002

Oviatt, B. M., \& McDougall, P. P. (1994). Toward a theory of international new ventures. Journal of International Business Studies, 25(1), 45-64. https://doi.org/10.1057/palgrave.jibs.8490193

Oviatt, B. M., \& McDougall, P. P. (1999). A framework for understanding accelerated international entrepreneurship. Research in Global Strategic Management, 7, 23-40. https://doi.org/10.1016/S1064-4857(99)07055-2

Oviatt, B. M., \& McDougall, P. P. (2005). Defining international entrepreneurship and modeling the speed of internationalization. Entrepreneurship theory and practice, 29(5), 537-553. https://doi.org/10.1111/j.1540-6520.2005.00097.x

Øyna, S., \& Alon, I. (2018). A Review of Born globals. International Studies of Management \& Organization, 48(2), 157-180. https://doi.org/10.1080/00208825.2018.1443737

Pagani, M., \& Pardo, C. (2017). The impact of digital technology on relationships in a business network. Industrial Marketing Management, 67(May), 185-192. https://doi.org/10.1016/j.indmarman.2017.08.009

Pham, T. S. H., Monkhouse, L. L., \& Barnes, B. R. (2017). The influence of relational capability and marketing capabilities on the export performance of emerging market firms. International Marketing Review, 34(5), 606-628. https://doi.org/10.1108/IMR-07-2014-0235

Porter, M. E. (1981). The contributions of industrial organization to strategic management. Academy of management review, 6(4), 609-620. https://doi.org/10.5465/amr.1981.4285706

Prange, C., \& Verdier, S. (2011). Dynamic capabilities, internationalization processes and performance. Journal of World Business, 46, 126-133. https://doi.org/10.1016/j.jwb.2010.05.024

Raymond, L., Bergeron, F., \& Croteau, A. M. (2013). Innovation capability and performance of manufacturing SMEs: The paradoxical effect of IT integration. Journal of Organizational Computing and Electronic Commerce, 23(3), 249-272. https://doi.org/10.1080/10919392.2013.807714

Rennie, M. W. (1993). Born global. The McKinsey Quarterly, 4, 45-53.

Sinkovics, N., Sinkovics, R. R., \& "Bryan" Jean, R. J. (2013). The internet as an alternative path to internationalization? International Marketing Review, 30(2), 130-155.

https://doi.org/10.1108/02651331311314556 
Sok, P., \& Cass, A. O. (2011). Achieving superior innovation-based performance outcomes in SMEs through innovation resource - capability complementarity. Industrial Marketing Management, 40(8), 1285-1293. https://doi.org/10.1016/j.indmarman.2011.10.007

Song, M., Nason, R. W., \& Di Benedetto, C. A. (2008). Distinctive marketing and information technology capabilities and strategic types: A cross-national investigation. Journal of International Marketing, 16(1), 4-38. https://doi.org/10.1509/jimk.16.1.4

Takahashi, A., Bulgacov, S., Semprebon, E., \& Giacomini, M. (2016). Dynamic capabilities, marketing capability and organizational performance. Brazilian Business Review, 14(5), 466-478. https://doi.org/10.15728/bbr.2017.14.5.1

Teece, D., Pisano, G., \& Shuen, A. (1997). Dynamic capabilities and strategic management. Strategic Management Journal, 18(7), 509-533. https://doi.org/10.1002/(SICI)1097-0266(199708)18:7<509::AID-SMJ882>3.0.CO;2-Z

Vahlne, J. E., \& Johanson, J. (2017). From Internationalization to Evolution: The Uppsala Model at 40 years. Journal of International Business Studies, 48(9), 1087-1102. https://doi.org/10.1057/s41267-017-0107-7

Weerawardena, J. (2003). The role of marketing capability in innovation-based competitive strategy. Journal of Strategic Marketing, 11(1), 15-35. https://doi.org/10.1080/0965254032000096766

Weerawardena, J., Mort, G. S., Liesch, P. W., \& Knight, G. (2007). Conceptualizing accelerated internationalization in the born global firm: A dynamic capabilities perspective. Journal of World Business, 42(3), 294-306. https://doi.org/10.1016/j.jwb.2007.04.004

Wilden, R., Gudergan, S. P., \& Nielsen, B. B. (2013). Dynamic capabilities and performance : Strategy , structure and environment. Long Range Planning, 46(1-2), 72-96. https://doi.org/10.1016/j.lrp.2012.12.001

Wu, H., Chen, J., \& Jiao, H. (2016). Dynamic capabilities as a mediator linking international diversification and innovation performance of firms in an emerging economy. Journal of Business Research, 69(8), 2678-2686. https://doi.org/10.1016/j.jbusres.2015.11.003

Zahra, S. A., Ireland, R. D., \& Hitt, M. A. (2000). International expansion by new venture firms: international diversity, mode of market entry, technological learning, and performance. Academy of Management Journal, 43(5), 925-950. https://doi.org/10.2307/1556420

Zhang, M., Sarker, S., \& Sarker, S. (2013). Drivers and export performance impacts of IT capability in 'born global'firms: a cross national study. Information Systems Journal, 23(5), 419-443. https://doi.org/10.1111/j.1365-2575.2012.00404.x

Zhang, M., \& Tansuhaj, P. (2007). Organizational culture, information technology capability, and performance: the case of born global firms. Multinational Business Review, 15(3), 43-78. https://doi.org/10.1108/1525383X200700012

Zhou, L., Wu, W. P., \& Luo, X. (2007). Internationalization and the performance of born-global SMEs: The mediating role of social networks. Journal of International Business Studies, 38(4), 673-690. https://doi.org/10.1057/palgrave.jibs.8400282

\section{Copyrights}

Copyright for this article is retained by the author(s), with first publication rights granted to the journal.

This is an open-access article distributed under the terms and conditions of the Creative Commons Attribution license (http://creativecommons.org/licenses/by/4.0/). 